\title{
ISOLASI DAN UJI POTENSI BAKTERI ASAM LAKTAT ASAL KIMCHII DAN TEH KOMBUCHA DALAM MENGHAMBAT BAKTERI PATOGEN
}

\author{
Selamat Riadi, Dewi Setiyawati, Suryani Situmeang* \\ Jurusan Analis Kesehatan, Politeknik Kesehatan Kemenkes RI Medan \\ *Email: Situmeang.suryani@gmail.com
}

\begin{abstract}
ABSTRAK
Bakteri asam laktat dikenal luas sebagai bakteri probiotik yang dapat berfungsi sebagai antimikroba melalui metabolit yang dihasilkannya. Senyawa metabolit yang dihasilkan bakteri asam laktat memiliki kemampuan menghambat pertumbuhan mikroorganisme patogen. Senyawa aktif yang dihasilkan bakteri asam laktat tersebut disebut bakteriosin. Bakteriosin merupakan senyawa aktif yang dihasilkan oleh bakteri termasuk bakteri asam laktat yang berfungsi sebagai bakterisida. Habitat bakteri asam laktat salah satunya adalah di dalam makanan fermentasi. Teh kombucha dan fermentasi sayuran (kimchi) merupakan produk fermentasi yang dapat dibuat secara sederhana di rumah. penelitian ini dilaksanakan secara deskriptif dengan tahapan penelitian yaitu persiapan sampel, isolasi, pemurnian isolat, identifikasi isolate, uji antagonis dan uji senyawa bakteriosin. Berdasarkan hasil penelitian didapatkan 5 jenis isolat yaitu KT01, KT02, FK01, FK02 dan FK03. Keseluruhan isolat merupakan kelompok bakteri gram positif dengan variasi bentuk sel basil dan kokus. Isolat bakteri KT02 dan FK02 diketahui meghasilkan zona hambat terbesar terhadap ketiga jenis bakteri pathogen Eschericia coli, Salmonella thypii dan Shigella dysentriae.
\end{abstract}

Kata kunci: Bakteri asam laktat, kimchi, kombucha

\begin{abstract}
Lactic acid bacteria are widely known as probiotic bacteria that can function as antimicrobials through the metabolites they produce. Metabolite compounds produced by lactic acid bacteria have the ability to inhibit the growth of pathogenic microorganisms. The active compound produced by lactic acid bacteria is called bacteriocin. Bacteriocin is an active compound produced by bacteria including lactic acid bacteria that function as bactericides. One of lactic acid bacteria habitat is in fermented food. Kombucha tea and vegetable fermentation (kimchi) are fermented products that can be made simply at home. This research was carried out descriptively with the stages of the research namely sample preparation, isolation, isolation purification, identification of isolates, antagonistic test and bacteriocin compound test. Based on the results of the study found 5 types of isolates namely KT01, KT02, FK01, FK02 and FK03. All isolates were a group of gram-positive bacteria with variations in the shape of bacilli and cocci cells. The bacterial isolates of KTO2 and FKO2 are known to produce the largest inhibitory zones against the three types of pathogenic bacteria Eschericia coli, Salmonella thypii and Shigella dysentriae.
\end{abstract}

Keywords: lactic acid bacteria, kimchi, kombucha

\section{PENDAHULUAN}

Bakteri Asam Laktat (BAL) banyak digunakan dalam berbagai industri makanan dan minuman sebagai hasil suatu fermentasi. Mikroorganisme tersebut berperan dalam perubahan tekstur, aroma, warna dan kualitas produk fermentasi. Bakteri Asam Laktat (BAL) menjadi pilihan yang tepat karena sifatnya tidak toksik sehingga aman digunakan. Efek antimikroba bakteri asam laktat ini disebabkan oleh pembentukan asam laktat dan asam asetat serta penurunan $\mathrm{pH}$ yang dihasilkan. Selain itu bakteri asam laktat juga menghasilkan senyawasenyawa penghambat lain seperti hidrogen peroksida, diasetil, karbondioksida, reuterin dan bakteriosin. $^{1}$

Bakteriosin merupakan senyawa protein yang disekresikan oleh bakteri yang bersifat menghambat pertumbuhan bakteri lain terutama yang memiliki kekerabatan secara filogenik. Senyawa ini mudah terdegredasi oleh enzim proteolitik dalam pencernaan manusia dan hewan. Bakteriosin berpotensi sebagai pengawet makanan alami dan dapat diaplikasikan di bidang farmasi. Beberapa bakteriosin mempunyai spektrum yang luas dan mempunyai aktivitas menghambat pertumbuhan beberapa bakteri patogen makanan. 
Beberapa spesies bakteri asam laktat dilaporkan menghasilkan bakteriosin seperti laktocin 27 oleh L.helveticus LP 27, lactacin F L.acidhophilus 88, plantacin B oleh L.plantarum NCDO 1193, Sakacin A oleh L.sake LB 706, brevicin 37 oleh L.brevis B37. Senyawa antimikroba adalah senyawa biologis atau kimia yang dapat menghambat pertumbuhan dan aktivitas mikroba. Zat antimikroba dapat bersifat bakterisidal (membunuh bakteri), bakteristatik (menghambat pertumbuhan bakteri), fungisidal, fungistatik atau menghambat germinasi spora bakteri. Kemampuan suatu zat antimikroba dalam menghambat pertumbuhan mikroba dipengaruhi oleh berbagai faktor, yaitu: (1) konsentrasi zat antimikroba, (2) suhu lingkungan, (3) waktu penyimpanan, (4) sifat-sifat mikroba, meliputi jenis, jumlah, umur, dan keadaan mikroba, (5) sifat-sifat fisik dan kimia makanan termasuk kadar air, $\mathrm{pH}$, jenis, dan jumlah senyawa di dalamnya. ${ }^{2}$

Metabolit yang bersifat antimikroba yang diproduksi oleh BAL dapat dibagi menjadi dua grup: 1) komponen bermassa molekul rendah, misalnya asam organik yang mempunyai spektrum aksi yang luas dan 2) protein antimikrobial, dikenal sebagai bakteriosin, yang secara relatif mempunyai aksi spesifik melawan organisme lain yang mempunyai hubungan dekat dan bakteri Gram positif lainnya. ${ }^{3}$

Bakteri asam laktat dapat diisolasi dari berbagai sumber antara lain dari makanan fermentasi. Teh kombucha dan fermentasi sayuran (kimchi) merupakan produk fermentasi yang dapat dibuat secara sederhana dan memiiki manfaat sebagai antioksidan. Berdasarkan manfaat tersebut, maka kedua produk ini mulai dikonsumsi secara luas oleh masyarakat.

\section{METODE PENELITIAN}

Metode penelitian yang digunakan adalah deskriptif. Data penelitian ditampilkan dalam bentuk tabulasi. Tahapan penelitian adalah sebagai berikut: preparasi sampel, peremajaan dan konfirmasi isolat patogen, isolasi bakteri asam laktat dari sampel, identifikasi bakteri asam lakat dan uji antagonis. Uji antagonis dilakukan dengan metode difusi cakram atau Kirby-Bauer.

\section{HASIL DAN PEMBAHASAN}

Konfirmasi bakteri patogen dilakukan dengan menumbuhkan isolat bakteri patogen di dalam media selektif dan dengan melakukan meliputi pewarnaan gram dengan mengamati bentuk dan penataan sel. Escherichia coli adalah bakteri Gram negatif yang berbentuk batang pendek lurus (kokobasil), tidak memiliki kapsul dan tidak memiliki spora. (4) Shigella dysentriae adalah merupakan kelompok bakteri gram negatif, non motil, mampu membentuk endospora. Bakteri ini adalah kelompok Enterobacteriaceae, yang memiliki sifat anaerob fakultatif. Selian itu, E. coli juga memiliki flagel peritrik sehingga bersifat motil positif. Salmonella thypii adalah jenis bakteri gram negatif, berbentuk batang, motil, serta mempunyai tipe metabolisme yang bersifat anaerob fakultatif. Termasuk kelompok bakteri Enterobacteriaceae. ${ }^{5}$

Tabel 1. Karakteristik mikroskopis bakteri patogen

\begin{tabular}{cccc}
\hline Bakteri & Gram & Bentuk sel & Penataan sel \\
\hline Escheria coli & Negatif & Basil & -mono, -diplo \\
Salmonella thypii & Negatif & Basil & -mono \\
Shigella dysentriae & Negatif & Basil pendek & -mono \\
\hline
\end{tabular}

Isolasi bakteri asam laktat dari fermentasi teh kombucha dan kimchi telah dilakukan. Didapatkan 5 isolat bakteri asam laktat yaitu KT01, KT02, FK01, FK02 dan FK03. Kelima isolat bakteri asam laktat tersebut memiliki perbedaan karakteristik secara visual yang meliputi perbedaan warna, bentuk, tepi dan elevasi koloni bakteri tabel 2. 
Tabel 2. Karakteristik visual bakteri asam laktat dari fermentasi teh kombucha dan kimchi

\begin{tabular}{lcccc}
\hline Isolat & Warna & Bentuk & Tepi & Elevasi \\
\hline KT01 & Putih & Bundar & Licin & Timbul \\
KT02 & Putih & Tak beraturan dan menyebar & Tak beraturan & Cembung \\
FK01 & Kuning & Bundar & Licin & Cembung \\
FK02 & Kuning & Rizoid & Berombak & Timbul \\
FK03 & Putih & Tak beraturan dan menyebar & Tak beraturan & Cembung \\
\hline
\end{tabular}

Ket: KT (isolat asal teh kombucha) dan FK (isolat asal fermentas kimchi)

Berdasarkan tabel 2, dapat dilihat karakteristik kelima isolat bakteri asam laktat asal fermentasi teh kombuha dan kimchi. Isolat bakteri KT01 dan FK03 memiliki warna koloni yang sama yaitu putih. Sedangkan isolat bakteri KT02, FK01 dan FK02 memiliki warna koloni kuning.

Kelima jenis isolat bakteri memiliki 2 variasi bentuk morfologi yaitu bundar dan tak beraturan dengan koloni menyebar. Sementara itu, terdapat 3 variasi tepi koloni yaitu cembung dan timbul. Tepi koloni bakteri juga berbeda antara satu jenis isolat dengan isolat lainnya yaitu licin, tak beratiran dan berombak. Jumlah koloni bakteri yang ditemukan setelah masa inkubasi dapat dilihat pada tabel 3 berikut ini

Tabel 3. Jumlah koloni BAL pada media dengan metode total plate count (TPC)

\begin{tabular}{lcccc}
\hline Isolat & U1 & U2 & U3 & Rerata \\
\hline KT01 & 57 & 60 & 42 & 53 \\
KT02 & 20 & 15 & 13 & 16 \\
FK01 & 110 & 91 & 105 & 102 \\
FK02 & 88 & 75 & 80 & 81 \\
FK03 & 11 & 8 & 14 & 11 \\
\hline
\end{tabular}

Ket: cfu (colony forming unit)

Jumlah koloni bakteri yang dihitung dalam media setelah masa inkubasi yang terbanyak adalah isolat FK01 yaitu 102 cfu dan FK02 yaitu 81 cfu. Jumlah koloni isolat KT01, KT02 dan FK03 masing - masing adalah $53 \mathrm{cfu}, 16 \mathrm{cfu}$ dan $11 \mathrm{cfu}$. Perhitungan jumlah koloni dilakukan dengan metode total plate count (TPC). Prinsip dari metode TPC adalah menumbuhkan sel bakteri hidup pada media agar, sehingga bakteri yang dimaksud akan tumbuh dan membentuk koloni yang dapat dilihat langsung dan dihitung tanpa menggunakan mikroskop. Metode ini merupakan metode yang paling sederhana untuk menentukan jumlah mikroorganisme. Dalam melakukan metode TPC Teknik pengenceran harus dilakukan, agar memudahkan penghitungan jumlah bakteri yang tumbuh.
Isolat bakteri asam laktat merupakan kelompok bakteri gram positif. Isolat bakteri KT01, FK01 dan FK03 diketahui berbentuk bulat dan isolat bakter FK02 dan KT02 diketahui berbentuk batang. Pewarnaan Gram dilkukan untuk membedakan kelompok bakteri gram negatif dan gram positif. Pada kelompok bakteri gram positif, sel bakteri akan berwarna ungu. Sedangkan bakteri gram negatif, sel bakteri akan berwarna merah.

Selain pengamatan secara visual dan mikroskopis dilakukan pula analisis secara fisiologis dengan melakukan uji biokimia sederhana diantaranya uji metabolisme karbohidrat, metabolisme sitrat, uji pemecahan hidrogen peroksida (katalase) dan uji hidrolisa gelatin. Karakteristik kelima isolat bervariasi tersaji pada table.4.

Tabel 4. Karakteristik fisiologis isolat bakteri asam laktat

\begin{tabular}{lcccc}
\hline Isolat & Uji sitrat & Metabolisme karbohidrat & Gelatin & Katalase \\
\hline KT01 & + & $+(k / k)$ & - & - \\
KT02 & - & $+(k / k)$ & - & - \\
FK01 & + & $+(k / k)$ & - & - \\
FK02 & + & $+(k / k)$ & - & - \\
FK03 & - & $+(k / k)$ & - & - \\
\hline
\end{tabular}


Bakteri Asam Laktat merupakan kelompok bakteri yang membentuk asam laktat, sebagai produk utama dalam metabolisme karbohidrat. Bakteri asam laktat memiliki sifat katalase negatif, tidak memproduksi gas dan mampu memfermentasikan karbohidrat. ${ }^{6}$
Kemampuan bakteri asam laktat dalam menghambat bakteri patogen ditunjukkan dengan adanya zona hambat berupa daerah jernih di sekitar koloni bakteri patogen. Variasi nilai zona hambat setiap isolat bakteri asam laktat terhadap bakteri Eschericia coli disajikan pada table 5.

Tabel 5. Nilai zona hambat isolat bakteri asam laktat terhadap bakteri pathogen

\begin{tabular}{cccc}
\hline Isolat & E. coli & Zona Hambat (mm) & S. dysentriae \\
KT01 & 12.22 & S. thypii & 12.49 \\
KT02 & 21.97 & 10.35 & 21.00 \\
FK01 & 9.01 & 20.10 & 8.01 \\
FK02 & 28.01 & 8.56 & 19.20 \\
FK03 & 7.58 & 19.30 & 7.00 \\
\hline
\end{tabular}

Kelima isolat bakteri asam laktat mampu menghambat bakteri patogen, dengan nilai zona hambat bervariasi. Nilai zona hambar terbesar ditunjukkan oleh isolate KT02 dan FK02 terhadap ketiga jenis bakteri patogen. Mekanisme penghambatan pertumbuhan bakteri patogen oleh bakteri asam laktat dapat terjadi dengan beberapa cara diantaranya kerusakan dinding sel dengan cara menghambat sistesis dinding sel, perubahan permeabilitas membran yang menyebabkan terjadinya plasmolysis, penghambatan protein dan sistesis asam nukleta serta penghambatan kerja enzim. Penelitian Hanum menyatakan bahwa, bakteri Lactobacillus plantarum mampu menghambat Salmonella thypimurium dengan nilai zona hambat rerata sebesar $9.39 \mathrm{~mm}^{7}$

Ogunbanwo et al (2003) menyatakan bahwa isolat Lactobacillus plantarum dan Lactobacillus brevis mampu menghambat Eschericia coli. Hasil penelitian Yolanda \& Meitiniarti (2017) menyebutkan bahwa isolat bakteri asam laktat yang diperoleh dari kimchi mampu menghambat pertumbuhan Staphylococcus aureus dan Eschericia coli dengan rerata zona hambat berkisar antara $7-17 \mathrm{~mm}$. Penelitian Fitrianarni et al (2014) yang menyebutkan bahwa, susu fermentasi yang mengandung bakteri asam laktat Streptococcus thermophilus dan Lactobacillus bulgaricus mampu menghambat pertumbuhan $S$. dysentriae. Pada penelitian ini terbentuk clear zone (zona bening) yang disebabkan oleh pengaruh penurunan $\mathrm{pH}$ akibat terbentuknya asam organik melalui proses fermentasi. Rendahnya $\mathrm{pH}$ lingkungan di sekitar koloni bakteri $S$. dysenteriae menyebabkan ketidakseimbangan $\mathrm{pH}$ internal sel dan $\mathrm{pH}$ eksternal sel. Selanjutnya ion $\mathrm{H}+$ dari luar berdifusi ke dalam sel sehingga menyebabkan plasmolisis sel dan menyebabkan enzim, molekul serta protein terdenaturasi serta berujung pada kematian sel. ${ }^{8}$

\section{KESIMPULAN}

Diperoleh lima isolat bakteri asam laktat yaitu KT01 dan KT02 asal fermentasi teh kombucha serta FK01, FK02 dan FK03 asal kimchi. Kelima isolat bakteri asam laktat KT01, KT02, FK01, FK02 dan FK03 mampu menghambat bakteri patogen Eschericia coli, Salmonella thypii dan Shigella dysentriae yang membuktikan kelima isolat tersebut memiliki daya antibakteri.

\section{REFERENS}

1. Vuyst, L. dan E.J. Vandamme. Antimicrobial potential of lactic acid bacteria In: De Vuyst, L. dan E.J. Vandamme. Bacteriocins of lactic acid bacteria: microbiology, genetic and application. London: Blackie Academic \& Professional; 1994

2. Frazier WC \& Westhoff DC. Food Microbiology 4th ed. New York: Mc Graw Hill Publ. Co. Ltd.; 1988.

3. Kusumawati, N. Peranan Bakteri Asam Laktat dalam Menghambat Listeria monocytogenes pada Bahan Pangan. Jurnal teknologi pangan dan gizi. 2000;1(1): 10-15.

4. Frans G, Ujing \& Henny AD. Karakteristik Bakteri Pereduksi Merkuri (Escherichia coli) Diisolasi dari Perairan Pantai Teluk Manado. Jurnal Perikanan dan Kelautan Tropis. 7(3): 103 - 108. 2011. 
5. Lay B. Analisa Mikroba di Laboratorium. PT. Raja Grafindo Persada. Jakarta; 1994

6. Nur F, Hafsani \& Wahdinar A. Isolasi Bakteri Asam Laktat Berpotensi Probiotik Pada Dangke Makanan Tradisional dari Susu Kerbau di Curio Kabupaten Enrekang. Biogenesis. 2015;3(1): $60-65$.
7. Hanum Z. Kemampuan Susu Fermentasi Lactobacillus plantarum Menghambat Salmonella typhymurium Secara In Vitro. 2010;10 (2): 77 - 86.

8. Gildberg, A. Mikkelsen, Sandaker, E. and Ring, E. Probiotic Effect of Lactid Acid Bacteria in The Feed on Growth and Survival of Fry of Atlantic Cod (Gadus morhua) Hydrobiologia. Appl, Microbiology. 1997;352: 